\title{
TAGLN Gene
}

National Cancer Institute

\section{Source}

National Cancer Institute. TAGLN Gene. NCI Thesaurus. Code C114523.

This gene is involved in actin crosslinking. 